\title{
Imagem, raça e humilhação no espelho negro da nação: cultura visual, política e "pensamento negro" brasileiro durante a ditadura militar*
}

\author{
Francisco das Chagas Fernandes Santiago Júnior \\ Universidade Federal do Rio Grande do Norte \\ Natal, RN, Brasil \\ Santiago.jr@gmail.com
}

\section{RESUMO}

Este artigo problematiza as relações entre cultura visual, "racialização" e novas sensibilidades políticas no Brasil de meados dos anos 1970 e princípios dos 1980 a partir das discussóes da imagem e da representação do negro no cinema brasileiro. Observamos algumas das características da atualizaçáo e modificação da noção de raça no Brasil a partir da discussão sobre filmes brasileiros pelos representantes do que chamamos no texto de "pensamento negro", uma tradiçáo reflexiva em formação que questionou como a intelectualidade brasileira concebia a cultura negra. A reflexão negra se apresenta num conjunto de escritos na imprensa nos quais desenvolveram uma retórica da imagem do negro como retórica de humilhação racial. A denúncia da humilhação negra na imagem produzida pelos brancos permitiu a constituição de uma nova identidade racial no Brasil.

Palavras-chave: cinema brasileiro; identidade racial; Xica da Silva; Tenda dos Milagres; cultura visual; cultura política; intelectualidade negra.

\begin{abstract}
This article analyzes the relationship between visual culture, "racialization," and new political sensitivities in Brazil in the mid-1970s and early 1980s from the perspective of image and representation of Blacks in the Brazilian cinema. By examining the debate about Brazilian movies among those we call representatives of a "Black thought" in Brazil, we observed some characteristics of change and update of the notion of race in Brazil, within a rising reflective tradition that questioned the views of the Brazilian intelligentsia on Black culture. This Black thought is presented through a set of articles published in the press, where the rhetoric of the image of Blacks was equated to a rhetoric of racial humiliation. The denunciation of the humiliation of Blacks in the image produced by Whites allowed the establishment of a new racial identity in Brazil.
\end{abstract}

Keywords: Brazilian cinema; racial identity; Xica da Silva; Tenda dos Milagres; visual culture; political culture; Black intellectuals.

\footnotetext{
* Este trabalho sintetiza e amplia alguns dados de minha tese de doutoramento, financiada com bolsa Fapern/Capes, sob orientação de Ana Maria Mauad. Uma versão resumida foi apresentada no XXVI Simpósio Nacional da Anpuh. Cf. SANTIAGO JR., Francisco das C. F. Reaçôes na (à) cultura visual: racialização e humilhação no Brasil dos anos 1970. In: SIMPÓSIO NACIONAL DE HISTÓRIA, XXVI, 2011, São Paulo. Anais eletrônicos. Disponível em: <www. snh2011.anpuh.org/resources/anais/14/1300889176_ARQUIVO_Reacoesna\%28a\%29culturavisual.pdf>. Acesso em: 12 mar. 2012.
}

Artigo recebido em 3 de novembro de 2011 e aceito em 1ํo de abril de 2012. 
As relaçóes entre formaçóes da cultura visual, raça e imaginário político têm sido foco de importantes indagaçôes sobre como hierarquias e classificaçóes identificatórias estabelecem vínculos sociais nas sociedades. Os estudos visuais têm evidenciado que mais do que veiculação, mídias como o cinema conferem espessura de sentido às realidades políticas, configurando, a partir de práticas visuais, um conjunto de condutas sociais e referências de valores que, nas/pelas imagens, permitem deslocamentos das práticas políticas ${ }^{1}$. Existe, portanto, um vínculo entre cultura política e cultura visual que a história das imagens em múltiplas modalidades tem explorado².

Paul Gilroy tem investido na crítica do papel das imagens na construção das práticas de poder que inscreveram negros enquanto comunidades e corpos racializados inseridos na própria dinâmica do poder imperial europeu e, mais tarde, norte-americano ${ }^{3}$. Chamando atenção para a necessidade de pensar a alteridade negra a partir da constituição da cultura visual que elabora imagens dos negros, Gilroy aponta a transformação que a visualidade produz nas formas de solidariedade, identificação e pertencimento mais gerais e microscópicos.

Este estudo se insere na construção de bases para uma crítica da raciologia na história da visualidade do Brasil recente, uma vez que indaga sobre a maneira como o conceito de raça foi reconstruído nos anos 1970 a partir do questionamento da imagem do negro no campo cinematográfico. Filmes como Xica da Silva (1976) e Tenda dos Milagres (1977) causaram reaçóes adversas na imprensa brasileira e permitem rastrear algumas das maneiras pelas quais certos intelectuais questionaram a identidade do negro por meio da imagem fílmica. Em jornais, periódicos e textos acadêmicos, entre 1974 e 1983, encontramos uma nova categorização racial elaborada como uma retórica da humilhação. Esses discursos criaram bases para perspectivas raciais do que aqui chamamos de "pensamento negro", tradição que era construída pelos intelectuais negros sobre sua própria condição.

O cinema brasileiro agenciou velhas mitologias políticas, as quais foram deslocadas por pensadores negros, interessados em reconstruir a agenda política brasileira a partir da noção de raça. Trataremos, portanto, da reconstrução da cultura política relacionada à identidade negra no Brasil de meados da ditadura militar, na elaboração de novos parâmetros de visualização negra. Identificamos, inicialmente, em polêmicas na imprensa sobre filmes nacionais uma série de posicionamentos de intelectuais negros ante a forma como o negro era mostrado no Brasil da década de 1970.

O artigo que segue trata da história da apropriação da noçáo de raça no Brasil nos anos 1970 e de como esta deslocou o imaginário e a sensibilidade política no Brasil a partir de uma indagação visual. Nossa hipótese é que a reação contra as referências visuais negras vigentes forneceu bases para novas referências visuais. Observaremos as categorizaçôes do negro no campo cinematográfico brasileiro nos anos 1960 e suas modificaçóes a partir de 1974. Em seguida, mostraremos a maneira como a raça foi atualizada, no Brasil, por intelectuais negros que questionaram a imagem do negro no país, apontando como tais filmes compunham uma retórica da humilhação, a qual constituía uma nova retórica da diferença com bases na cultura visual.

\footnotetext{
${ }^{1}$ Cf. MITCHELL, W. Teoría de la imagen. Madri: Akal, 2009.

${ }^{2}$ Cf. CLARK, T. J. Modernismos. São Paulo: Cosac \& Naify, 2007; GRIEVESON, Lee. Policing cinema: movies and censorship in early-Twentieth-Century America. Los Angeles: University of California Press, 2004; SHOHAT, Ella; STAM, Robert. Critica da imagem eurocêntrica. São Paulo: Cosac \& Naify, 2005.

${ }^{3}$ Tratamos a ideia de "raça" como um padrão formado a partir de um conjunto de práticas e tropos (uma retórica nem sempre concordante) que sistematizam as diferenças sociais a partir da aparência e da origem. É importante distinguir entre concepçóes racistas (referentes ao comportamento que costuma envolver medo, desprezo ou ódio contra pessoas de aparência definida) e concepçóes racialistas (referentes à ideologia, que se apropriam de padróes raciais para o combate ao racismo). Cf. GILROY, Paul. Entre campos: naçóes, culturas e o fascínio da raça. São Paulo: Annablume, 2007; TODOROV, Tzvetan. Nós e os outros. Rio de janeiro: Zahar, 1993.
} 


\section{Da retórica da classe à retórica da raça}

O campo cinematográfico viu-se às voltas com a questão do negro na politização da prática fílmica a partir de meados dos anos $1950^{4}$. Naqueles anos, quando surgiram manifestaçóes culturais importantes, o cinema tornou-se um campo cultural no qual se discutiam os destinos políticos do país e o negro tornava-se um dos muitos temas dos filmes. Fitas como Bahia de Todos os Santos (1961), Barravento (1961), Assalto ao Trem Pagador (1962), Ganga Zumba (1964), Integração racial (1964) apresentaram a integração do negro na sociedade. Para alguns cineastas, tratar do negro era uma das maneiras de mostrar desigualdades sociais mais amplas, as quais, na época, foram pensadas pelo viés socioeconômico, uma das faces do debate de classe no Brasil ${ }^{6}$.

A classificação racial e a atribuição de origem africana nas fitas denunciavam um tipo específico de vítima da exploração econômica, o negro brasileiro. Intelectuais, artistas e ativistas políticos pautavam a exploração dos diversos segmentos da população brasileira. Expressôes como "cultura negra" ou "situação do negro" foram invocadas como sinais da exclusão econômica que estruturava a sociedade brasileira. O reconhecimento do negro como um tema cinematográfico, a partir dos anos 1960, ocorreu por meio de temas históricos (a escravidão) ou da cultura popular (a religiosidade). Questáo racial e racismo derivavam da desigualdade social e alguns cineastas e críticos se dedicaram a esclarecer o povo sobre sua condição. Contudo, quando a conscientização atingia a raça, geraram-se incômodos. O primeiro longa-metragem de Carlos Diegues, Ganga Zumba, rei de Palmares (1964) ${ }^{7}$, permite-nos observar esse ponto.

A fita de Diegues contava a fuga de Ganga Zumba de um engenho e sua chegada ao quilombo dos Palmares, do qual seria importante líder. Nos filmes da década anterior, tais como Rio 40 graus (1955) ou Rio Zona Norte (1957), as tramas inseriam os negros na contemporaneidade, mas Diegues realizara um filme histórico sobre resistência escrava. Entre as interpretaçôes correntes, o crítico Cláudio de Souza defendeu:

Já cheguei a ouvir que se trata de um filme racista, porque aborda uma realidade negra com atores negros. Santa estupidez, pois a prosseguirmos neste caminho vamos também chegar à conclusão de que a história do Brasil, com tantos capítulos africanos, é racista em sua maior parte. O filme não é nada disso, leitor. Ganga Zumba parece ser, mais exatamente, um canto à liberdade. Não à liberdade como um sentimento abstrato e transcendental, mas àquela liberdade de existir, de viver e de conviver, liberdade essencial de subsistir como homem e que está na base de nossa vida de todos os minutos ${ }^{8}$.

O crítico apontou a ausência do racismo uma vez que não era a presença dos negros, na estória, o tema central, mas a liberdade. Ao mesmo tempo, afirmou que a história do Brasil não poderia ser racista com seus "capítulos africanos". A resistência à opressão e a luta do negro não eram temas em si, mas um reflexo da busca universal pela "liberdade de subsistir como homem". O negro, como raça, fora apagado nesse discurso, e a escravidáo tornara-se um ato de privação do homem pelo homem, não do branco pelo negro.

\footnotetext{
${ }^{4}$ Embora filmes que toquem na questão racial sejam anteriores, como o clássico Também somos irmãos (1949), além de Rio 40 graus (1955) e Rio Zona Norte (1957).

${ }^{5} \mathrm{Nem}$ todos estes filmes estavam vinculados ao cinema novo.

${ }^{6}$ Não queremos com isso dizer que os filmes não representavam as tensões raciais, mas apontar que essas tinham um papel definido no quadro das relaçôes econômico-sociais.

${ }^{7}$ Além de ser um dos temas principais na obra de Carlos Diegues como um todo.

${ }^{8}$ SOUZA, Cláudio Mello e. Ganga Zumba domina a semana. Jornal do Brasil, Rio de Janeiro, 3 mar. 1964. Caderno B, p. 3.
} 
IMAGEM, RAÇA E HUMILHAÇÃO NO ESPELHO NEGRO DA NAÇÃO:

CULTURA VISUAL, POLÍTICA E “PENSAMENTO NEGRO” BRASILEIRO DURANTE A DITADURA MILITAR

Francisco das Chagas Fernandes Santiago Júnior

Menos sutil foi o crítico Luiz Alberto, do carioca Jornal do Comércio. Ganga Zumba já nascera alijado, ideologicamente

frustrado, desde o ponto em que a solução final é entre negros e brancos, desde que o equacionamento por todo o filme (em raríssimos diálogos a exceção que confirma a regra) é de uma luta pela libertação dos negros de sob os brancos e não dos explorados de sob os exploradores?.

Desta vez, a questáo racial era um equívoco porque a fita deixara de explorar o aspecto da exploração econômica, a base do sistema escravista. Desviar para o prisma da raça, segundo ele, não permitia perceber a raiz do problema histórico. Agora, em vez da liberdade, queria-se a luta de classes.

Já o diretor Carlos Diegues, antes do lançamento da película, afirmara que desejava um

filme simples, objetivo, direto sobre um tema que sempre desejei tocar, a liberdade, através de um instrumento cultural que sempre me interessou, o negro, sua cultura. Creio pelo que temos agora, que estamos alcançando o objetivo. "Ganga Zumba" terá de ser um filme violento (...) fundamental do espírito negro ${ }^{10}$.

A questão racial ou mesmo da escravidão, até o lançamento de Ganga Zumba, focalizou a apresentaçáo do negro a partir de uma perspectiva moralizante, usando de personagens-tipo que polarizavam os aspectos "imorais" do sistema: bons e maus senhores e escravos, independente da cor. Fitas como Sinhá Moça (1952) foram exemplos dessa chave moralizante. A politização do debate cultural brasileiro nos anos 1960 em Ganga Zumba permite observar o incômodo sobre o papel do negro e da raça no imaginário nacional.

Naquele contexto, a diferença de classe, a exploração e a liberdade eram alicerces das interpretaçóes das fitas dedicadas aos negros a partir de meados dos anos 1950. A discussão da escravidão, observada no discurso de Luiz Alberto, partia da ideia de liberdade, mas não ignorava a diferença de classe na situação do negro. Se na perspectiva de Alberto o filme de Diegues era racista porque transformava uma questáo de "exploradores" e "explorados" em negros contra brancos, a liberdade não podia ser pensada como uma alternativa à dominação racial, mas sim ao sistema econômico. Nas afirmaçôes da liberdade (Carlos Diegues e Souza), de racismo (Souza) ou de ignorância do fator econômico (Luiz Alberto), a reflexão racial era expulsa enquanto foco possível de reflexão sobre a imagem do filme. Exorcizou-se o racismo por uma imagem não racial da escravidão.

Entretanto, as artes brasileiras mudaram a partir de 1968. Apesar das críticas antecederem ao AI5, após o golpe, uma onda de autorreflexão atingira os campos culturais, inclusive o cinema. A versão fílmica de Macunaima (1968), de Joaquim Pedro de Andrade, marcou um desvio de rota. O filme reavaliou a personagem-símbolo de Mário de Andrade, e o próprio cineasta, numa "interpretação autojustificadora”, afirmara que Macunaíma era "um herói ultrapassado, um herói errado, um herói derrotado, é um herói de consciência individual; enquanto um herói moderno - evidentemente — é um herói de consciência coletiva e é um vencedor, não um derrotado"11.

A personagem revisada do modernismo mostrava as novas bricolagens que aconteciam nas artes brasileiras e que se efetivaram no tropicalismo, no cinema marginal e nos remanescentes do Cinema

\footnotetext{
${ }^{9}$ Cinemateca Brasileira. Centro de Documentação e Pesquisa. Pasta 109. ALBERTO, Luiz. Ganga Zumba. Jornal do Comércio, Rio de Janeiro, 20 mar. 1964.

${ }^{10}$ MORAES, Tânia. 'Ganga Zumba' quer dizer Zumbi (dos Palmares) e liberdade. Última Hora, Rio de janeiro, 29 ago. 1963. Cine Ronda, p. 12.

${ }^{11}$ ANDRADE, Joaquim Pedro de. Joaquim Pedro de Andrade por ele mesmo. In: RAMOS, Alcides Freire. Canibalismo dos fracos: cinema e história do Brasil. São Paulo: Edusc, 2002. p. 57.
} 
Novo, entre os quais se incluem Joaquim Pedro de Andrade, Glauber Rocha e Carlos Diegues. Antes, a politização iniciada pelos cineastas pretendia conscientizar o povo para a revolução, mas a repressão que se seguiu ao regime impediu tais perspectivas. Terra em transe (1967), de Glauber Rocha, junto a Fome de amor (1968), de Nelson Pereira dos Santos, foram fitas sobre a perda de rumo dos intelectuais com pretensóes de constituição de consciência política no povo. Essas obras eram mais do que reflexôes, mas intervençôes, no debate político, sobre o papel dos artistas, políticos e intelectuais numa revolução irrealizada. Parte dos cineastas se voltaria ao mundo dos chamados marginais, o universo underground (o udigrundi) do cinema marginal com suas propostas mais individualistas que expressavam um senso de inadequação social. Já os remanescentes do Cinema Novo deixaram de mostrar o povo como o agente revolucionário (um discurso perigoso naquele momento) para criar imagens do povo como um agente político de sua própria sobrevivência.

A cultura popular, antes concebida como alienação, foi retomada como campo no qual o povo realizaria suas estratégias para enfrentar as desigualdades e ganhar disputas. Filmes como O Dragáo da Maldade contra o Santo Guerreiro (1969) e a idealização do que o cineasta Nelson Pereira dos Santos chamou de "filme popular" (a fita que retratava a cultura do povo a partir de seus próprios valores e seria capaz de ampliar o público do cinema brasileiro), nos anos 1970, mostravam outra politização da cultura do povo no campo cinematográfico.

O segundo filme histórico sobre a escravidão de Carlos Diegues, Xica da Silva, fora realizado em meio a essas buscas por alternativas populares. A fita retomava o ideal modernista antropofágico como base da trama de trocas entre negros e brancos alegorizada no Arraial do Tijuco. Na película, lançada em 1976, a escrava Xica, um mito histórico pouco conhecido na época, usava da sensualidade para inverter as relaçóes sociais escravistas ${ }^{12}$. Xica impunha-se à nobreza branca e escarnecia dela ao imitá-la.

Muitos críticos, intelectuais e artistas aplaudiram a inversão da ordem social e a "estética carnavalesca" do filme. "O cinema brasileiro está procurando dirigir aos sentimentos do espectador certas ideias que, em filmes anteriores, foram endereçadas principalmente à razão do espectador”, afirmou José Carlos Avellar. Segundo ele, a película agia "duas vezes antes de pensar para desarrumar o que está falsamente arrumado. Esta é a ideia que Xica da Silva procura passar para o espectador através da açáo". Usando como arma o deboche e a avacalhação, as mazelas eram apontadas e desnudadas, fazendo de "Xica da Silva uma declaração de amor à exuberância do povo brasileiro, que eu tentei transmitir de maneira fantasiosa", disse Carlos Diegues ${ }^{13}$.

Houve, porém, os que acharam a fita um absurdo e transformaram drasticamente o debate racial. Em 15 de outubro de 1976, no jornal Opiniáo, Carlos Hansenbalg, Beatrix Nascimento e Carlos Frederico desfilaram críticas severas à fita entre as quatro páginas que o periódico havia lhe dedicado. Chocavam-se com a "estarrecedora unanimidade de opinióes" sobre a película. Tomaram-na como a uma pornochanchada:

Afinal, quem era Xica da Silva? Uma preta de alma tão branca e safada como a de qualquer Du Barry dos melhores salóes. Uma preta que gostava de dar ordens e ter escravos, como qualquer branca. Uma preta cheia de trejeito, que botava a boca no mundo por qualquer disse-me-disse; que gostava de fazer molecagens, tais como cuspir na comida dos outros etc., uma preta que, sobretudo, gostava de muito luxo e riqueza, e que, ainda por cima, tinha um borogodó secreto que fazia os homens darem urros estranhos de dor.

\footnotetext{
${ }^{12}$ Antes de Diegues, Antônio Callado escrevera um ato teatral sobre Xica da Silva nos anos 1950 na Escola de Teatro da Universidade da Bahia, com participação de Nevolanda Amorim e Othon Bastos.

${ }^{13}$ Cinemateca Brasileira. Centro de Documentação e Pesquisa. Pasta 495. DIEGUES, Carlos. Entrevista. O Estado de S. Paulo, São Paulo, 26 jun. 1976.
} 
IMAGEM, RAÇA E HUMILHAÇÃO NO ESPELHO NEGRO DA NAÇÃO:

CULTURA VISUAL, POLÍTICA E “PENSAMENTO NEGRO” BRASILEIRO DURANTE A DITADURA MILITAR

Francisco das Chagas Fernandes Santiago Júnior

Xica imita os ricos, os brancos, os déspotas, os poderosos, e curte adoidada ser como eles - e o filme aplaude, deslumbrado!... [grifos nossos] ${ }^{14}$.

O sociólogo Carlos Hasenbalg identificou na obra e em seu diretor a síntese do senso comum brasileiro e concluiu que "uma raça - no caso o branco brasileiro - pode coexistir durante séculos com outra - o negro brasileiro - e continuar a ignorar as verdades desta" [grifos nossos]:

Entre as múltiplas possibilidades de se fazer uma adaptação livre da história original, o diretor escolheu a versão mais ambigua, e aquela que condensa, no personagem principal, todos os preconceitos a respeito da mulher negra. Neste sentido, o filme retoma uma consagrada tradição literária que mistifica e romantiza os aspectos do negro mais estereotipados na cultura brasileira.

A estória trata da mobilidade "sexual" ascendente da escrava Xica, operada através da manipulação de um arsenal erótico (...). O ascenso de Xica é tão efêmero quanto a aventura de João Fernandes no Arraial do Tijuco. Como em toda mobilidade individual, o projeto de Xica é a-político [grifos nossos] ${ }^{15}$.

A historiadora Beatriz Nascimento exigiu a proibição da fita por ser um

desrespeito que impóe a um episódio da história de um povo, desrespeito quanto à história de todo um povo, desrespeito na medida em que vilipendia este povo, desrespeito por manter os estereótipos em relação a um povo que no momento procura, em função de sua autonomia cultural, se livrar justamente desses estereótipos ${ }^{16}$.

O trabalho de Diegues fugiria da veracidade histórica, desinformando a população e, "em termos da crítica das relaçóes raciais no Brasil, nos remete à Idade da Pedra" [grifos nossos]. Nascimento identificou a matriz ideológica da obra:

Repete como já dissemos Casa-grande e senzala. Os portugueses no filme, desde João Fernandes, passando pelo intendente, até o frouxo "inconfidente" são opressores, exploradores, mas complacentes com os negros, escravos, sentimentais (o pai do "Inconfidente" e João Fernandes) e, acima de tudo, bons apreciadores dos jogos do amor. Os negros, escravos e quilombolas são passivos, rebeldes inconsequentes (bandidos salteadores) e reconhecidos da bondade e generosidade do Senhor (...) O conflito racial (que não consegue transpirar satisfatoriamente) só parte das pessoas menos dotadas (...)

Em suma, o éthos português colonizador é de humanidade e reconhecimento da pessoa dos negros: uma escravidão amena e divertida [grifo nosso] ${ }^{17}$.

Finalmente, no final do artigo para Opiniāo, Nascimento faz sua grande crítica:

Confesso que perdi as esperanças quanto à compreensão do intelectual branco brasileiro sobre a real história do negro. (...)

Se o senhor Diegues descesse um pouco da sua onipotência e fizesse uma reflexão sobre si mesmo e a implicação da história do seu povo em si antes de confeccionar o filme, entenderia que, devido às relaçóes sociais e culturais,

\footnotetext{
${ }^{14}$ FREDERICO, Carlos. Abacaxica. Opinião. Rio de Janeiro, 15 out. 1976. Tendências e Cultura, p. 18.

${ }^{15}$ HASENBALG, Carlos. Copiando o senso comum. Opinião, Rio de Janeiro, 15 out. 1976. Tendências e Cultura, p. 19.

${ }^{16}$ NASCIMENTO, Beatrix. A senzala vista da casa grande. Opinião, Rio de Janeiro, 15 out. 1976. Tendências e Cultura, p. $20-21$.

${ }^{17}$ Ibidem.
} 
ele como um homem branco brasileiro possui introjetado, de forma específica, o negro brasileiro, sua posição em termos de homem e de raça. Mas ele, como a maioria dos seus iguais, deve ter um grande receio de descobrir esse ponto oculto [grifos nossos $]^{18}$.

A película de Diegues atingira frontalmente as sensibilidades de Frederico, Hanselbag e Nascimento, e esses três analistas eram alheios ao campo cinematográfico, intelectuais que indagaram a fita a partir de outro ponto de vista, e indicavam como dada parcela da populaçáo brasileira reagira à forma como os negros foram mostrados. Ao designarem o hábito "introjetado" dos “intelectuais brancos" de ignorar a história (Nascimento), de enveredar nos estereótipos (Hasenbalg) e de vilipendiar a mulher negra (Frederico), os analistas apontam problemas na sociedade brasileira - a Xica de "alma táo safada”, tão ansiosa por se passar por branca, era componente de uma imagem do negro que certos grupos sociais recusavam naquele momento.

Os três intérpretes identificaram o olhar branco em Xica da Silva e em seu realizador, Carlos Diegues: um olhar capaz de mostrar o negro, mas não de representá-lo; afinal, uma representação é representação para alguém e esse alguém não era, para eles, o "verdadeiro" negro. Um desses intelectuais, Beatriz Nascimento, se autodeclara negra para qualificar melhor sua posição, e ressaltar uma experiência de dentro da condiçáo negra. Todos racializaram a discussáo ao expor que havia um traço racial na própria composição do olhar, o qual, ao mesmo tempo, não permitia que aquelas imagens se tornassem uma representação dos negros e de sua história. Reprovaram protagonista, película e diretor, demarcando a diferença e a distância entre o povo negro, sua cultura e os "intelectuais [homens] brancos" brasileiros e suas produçóes. O negro passou a ser nomeado a partir das imagens criadas pelos brancos, as quais eram negadas como produçóes de brancos, caracterizados racialmente. Segundo as "leituras" racialistas aqui apontadas, Xica da Silva idealizava o negro para brancos, a visualização da "velha compreensão ocidental da África e do africano, como um primitivo, um selvagem"19.

Esse mesmo movimento é observado em polêmicas que surgiram sobre outro filme que lidava com a cultura negra e o encontro de raças no Brasil: Tenda dos Milagres, de Nelson Pereira dos Santos (1977). O sociólogo Muniz Sodré realizou a crítica representante de uma declarada perspectiva negra na revista IstoÉ. As disputas lançadas na sociedade por Tenda dos Milagres estariam relacionadas, segundo Sodré, com a defesa da mestiçagem e da democracia racial:

Em Tenda dos Milagres reproduz-se em sons e cores o éthos romancesco de Jorge Amado.

Mas — isto pode ser terrivelmente acaciano, porém necessário repetir — o filme de Nelson Pereira dos Santos fala mais do romance (da diegese) de Jorge Amado do que da realidade cultural baiana. E Amado, independentemente do valor estético de suas narrativas, representa apenas uma posição de classe sobre a Bahia. Esta posição, assumida pelo filme, é bastante discutível ${ }^{20}$.

Evidenciado que a leitura amadiana de Tenda dos Milagres, reforçada por Nelson dos Santos, não constitui uma representação fiel da realidade baiana, Sodré caracteriza a idealização:

Ela espelha [grifo nosso] o que poderíamos chamar de doutrina do mestiçamento. Em seus termos, a Bahia aparece como um cadinho de culturas e etnias, capaz de fornecer um modelo, miscigenado e sensual, para a consciência brasileira. A "civilização baiana" seria "mulata da melhor mulataria”. Posição idêntica adotava

\footnotetext{
${ }^{18}$ Ibidem.

${ }^{19}$ Ibidem.

${ }^{20}$ Cinemateca Brasileira. Centro de Documentação e Pesquisa. Pasta 630. SODRÉ, Muniz. Mulata da melhor mulataria. IstoÉ, São Paulo, 23 nov. 1977.
} 
Mário de Andrade quando, falando sobre danças dramáticas nacionais (bumba meu boi, maracatu, coco de praia etc.), chamava a atenção para a coreografia “já brasileira, já mestiça e própria”21.

Apesar do fenômeno da mestiçagem ser incontestável, principalmente no plano étnico, o estudioso afirmava que a "visão de mundo" que advém da "doutrina" era enganosa. Ela necessariamente implicaria a rejeição do

reconhecimento de uma cultura negra no Brasil, isto é, da existência de um complexo simbólico estruturado, com religião, normas, costumes, instituições, visão de mundo [grifo nosso] próprios. No entanto, esta cultura existe, movimenta e bole com a consciência de setores amplos da população nacional. Se as danças dramáticas, os ritmos, os mestiçamentos persistem — e na forma por todos conhecida —, é porque os mantém a força dos ritos e da cultura institucionalizada nos terreiros baianos [grifo do autor]. Nestas comunidades litúrgicoculturais está assentada a continuidade do simbólico negro no Brasil ${ }^{22}$.

Sodré se aparenta com a argumentação de Beatriz Nascimento ao indicar que deve ser difícil à mentalidade ocidental admitir a "heteroculturalidade". Logo o sociólogo sugere que Santos e Jorge Amado tendem a não encarar o pluralismo cultural e a conceber a cultura a partir do modelo dominante. Ambos dariam "um passo juntos na direção do reconhecimento de uma diferença presente na forma social brasileira: a cultura negra", mas "a tal doutrina do mestiçamento não leva a cultura negra a sério". O filme seria apenas uma promessa de entendimento da heterogeneidade cultural brasileira.

Observe-se que a cultura negra tomara o primeiro plano dos discursos na forma da ofensa em face da ignorância e do desrespeito dos brancos às "coisas" do povo negro. Há aqui um traço de identificação da humilhação sentida pelos agentes sociais que não se reconheciam na fita. O movimento que observamos nesses discursos era o da identificação de imagens dos negros que não são tomadas como imagens de si pelos próprios negros.

É evidente que a indagação sobre a imagem da nação nos filmes criada a partir do negro não era legítima para os intelectuais acima. Surgiu naquele momento, graças ao agenciamento das imagens da escravidão e da cultura negra no cinema, a possibilidade da politização pela racialização do debate. Contudo, tais discursos não surgiram do nada. Qual a base da reflexão contida nos discursos dos intelectuais que criticaram Xica da Silva e Tenda dos Milagres? Quais as vivências históricas e as matrizes discursivas que fundamentam esse deslocamento na concepção de raça? E qual o papel da reflexão visual, do uso das metáforas visuais na constituição de um novo horizonte político para o Brasil?

\section{A retórica da raça como retórica da imagem/identidade negra}

Os discursos de Beatriz Nascimento, Muniz Sodré, Carlos Frederico e Carlos Hasenbalg sobre os filmes Xica da Silva e Tenda dos Milagres apontam para uma modificação no cenário social e político brasileiro. Na tentativa de identificar o espectro do mundo político coberto por suas interpretaçóes, observamos que a redefinição da concepção racial como força política fazia parte da reformulação dos marcos políticos brasileiros na década de 1970. A nova retórica da raça estava alicerçada num contínuo movimento histórico que atingira o campo cinematográfico depois de ter tomado forma em outros campos sociais e culturais. Os discursos veiculados no jornal Opinião e na revista IstoÉ, para além de intervençóes no campo cinematográfico, alimentaram e foram alimentados por uma tradição que se

\footnotetext{
${ }^{21}$ Ibidem.

${ }^{22}$ Ibidem.
} 
formava, à qual chamaremos, por comodidade, de pensamento negro de artistas e intelectuais negros, os quais, em trocas intelectuais com outros setores da intelectualidade, montaram outra forma de compreensão social do Brasil.

O que foi esse pensamento negro? Muito deverá ser pesquisado para uma história social da intelectualidade negra no Brasil, mas suas bases já foram lançadas ${ }^{23}$. Embora possamos identificar as origens dos discursos de negros e mestiços sobre si próprios no século XIX, para efeito deste texto, o momento significativo fora a década de 1930 com a Frente Negra Brasileira (FNB), dedicada à inclusão do negro na sociedade brasileira e extinta durante o Estado Novo. Os componentes do FNB foram contemporâneos do surgimento de novas oportunidades para a população negra no mercado de trabalho, principalmente no setor público. $\mathrm{O}$ regime varguista restringiu a imigração e favoreceu a mão de obra nacional como parte do projeto de modernização.

$\mathrm{Na}$ década seguinte surgiu, em 1944, o Teatro Experimental do Negro, fundado por um destacado grupo de negros e negras que se dedicaram às atividades culturais e políticas de denúncia do preconceito e do estigma racial no Brasil. A nova organização realizou muitos eventos que formaram, no contexto da redemocratização pós-Estado Novo, uma nova estética e audiência para integração de negros e brancos e visibilizar o debate racial no Brasil ${ }^{24}$. O TEN fora fundado por Abdias do Nascimento, Aguinaldo de Oliveira Camargo, Teodoro dos Santos, José Herbal e Tibério. Trataram de criar um projeto de inclusão do negro defendendo que os negros brasileiros partilhavam do mesmo tipo de experiência de exclusão que os pobres. A associação negro-e-pobre fora criada pelo TEN na tentativa de formar uma arte e pensamento negros como expressão da maioria excluída e não da minoria racial ressentida ${ }^{25}$. $\mathrm{O}$ jornal $O$ Quilombo, organizado pelo TEN, foi a primeira publicação a sedimentar efetivamente uma reflexão crítica negra no Brasil ${ }^{26}$.

A sociologia contribuiu para a ampliação do arsenal teórico e ideológico de intelectuais e associaçóes negras que começaram a surgir no contexto da redemocratização. A partir dos anos 1950, a formaçáo da chamada "escola sociológica paulista" mostrava que a "democracia racial” era ideologia de um país repleto de preconceito racial. Florestan Fernandes, Roger Bastide, Fernando Henrique Cardoso passariam a ser base das releituras das relaçóes raciais no Brasil, ainda que alguns, como Fernandes, tomassem o racismo como sobrevivência pré-capitalista. Essa corrente de pensamento ergueu como importante inimigo Gilberto Freyre, que congregava o conservadorismo racista brasileiro em torno de sua figura, principalmente a partir dos anos 1950, quando o pernambucano insistira, cada vez mais, no lusotropicalismo.

Começaram a se destacar as obras de sociólogos negros como Alberto Guerreiro Ramos, que fundamentou uma revisão do papel do negro na cultura brasileira. Ramos trabalhou ativamente junto ao TEN e no jornal $O$ Quilombo, publicando artigos nos quais refletia sobre a questão racial e questóes de

\footnotetext{
${ }^{23}$ Cf. PEREIRA, Amilcar Araújo. O mundo negro: a constituição do movimento negro contemporâneo no Brasil (19751995). Tese (Doutorado em História) — Programa de Pós-Graduação em História, Universidade Federal Fluminense, Rio de Janeiro, 2010; PEREIRA, Amauri Mendes; SILVA, Joselina da (Org.). O movimento negro brasileiro: escritos sobre os sentidos de democracia e justiça no Brasil. Belo Horizonte: Nandyala, 2009; SIQUEIRA, José Jorge. Entre Orfeu e Xangô: a emergência de uma nova consciência sobre a questão do negro no Brasil 1944/1968. Rio de Janeiro: Pallas, 2006.

${ }^{24}$ Conferência Nacional do Negro (1946), Convençáo Nacional do Negro (1949), I Congresso Nacional do Negro (1950), este último realizado pela Associação Brasileira de Imprensa (ABI). Os Anais do I Congresso foram publicados em $O$ negro revoltado, organizado por Abdias do Nascimento (Rio de Janeiro: GRD, 1968).

${ }^{25}$ Cf. GUIMARÁES, Antonio Sergio Alfredo. Classe, raças de democracia. São Paulo: Ed. 34, 2004.

${ }^{26}$ Alguns autores apontam que essa reflexão, inclusive na elaboração de trocas de ideias transatlânticas, já ocorria na imprensa negra antes do jornal $O$ Quilombo. Cf. PEREIRA, Amilcar Araújo. Linhas (da cor) cruzadas: relaçóes raciais, imprensa negra e movimento negro no Brasil e nos Estados Unidos. In: PEREIRA, Amauri Mendes; SILVA, Joselina da (Org.). O movimento negro brasileiro: escritos sobre os sentidos de democracia e justiça no Brasil. Belo Horizonte: Nandyala, 2009. p. 109-126.
} 
ressentimento racial entre os homens negros. Apesar de não ter se dedicado propriamente à investigação das populaçóes negras, Ramos fora importante referência na visibilidade negra no Brasil para seus contemporâneos.

Aparentemente, o maior vetor de transformação no pensamento negro brasileiro foram os movimentos políticos e culturais negros estrangeiros. Popularizou-se no Brasil, desde principalmente os anos 1960, a partir de publicaçôes como a revista Realidade, reportagens sobre a questão racial no Brasil. Os movimentos de descolonização na África criavam um cenário de africanos (negros) lutando por seus direitos que se intensificou sobremaneira a partir da década de 1950, suscitando uma libertação do domínio europeu não apenas no sentido político, mas também ideológico. Finalmente, a onda norte-americana de movimentos sociais e luta pelos direitos civis com líderes carismáticos como Martin Luther King e Malcom X, ou a ação assertiva dos Panteras Negras, repercutiu no mundo todo, e no Brasil em particular, estimulando a criação de novas organizações negras no Brasil. Em depoimento, Hélio Silva afirmou:

Podemos identificar três matrizes de pensamento no discurso da geração que se engaja no movimento negro nos anos 1970 e 80 (...) Você tem o movimento pelos direitos civis nos Estados Unidos, que sempre mobilizou a atenção da militância; você tem as lutas independentistas no continente africano, sobretudo, até pela facilidade da proximidade linguística, nos países lusófonos (...) E por fim, o movimento pela négritude, que a rigor sempre foi um movimento literário na verdade, um movimento cultural de intelectuais de África e das Antilhas que se encontraram em Paris nos anos 30 do século passado e que vão formular algumas ideias a respeito do que seriam o ocidentalismo e o orientalismo na perspectiva africana, nos valores africanos ${ }^{27}$.

A negritude, revistas como a Ebony, escritos de Júlio de Castilhos ou o clássico de Frantz Fanon, traduzido para o português ainda na década de 1960, Os condenados da terra, tornaram-se importantes referências intelectuais para os negros brasileiros ${ }^{28}$. Multiplicaram-se gestos e símbolos de afirmação negra: o cabelo black power, a produção de músicas, festas e movimentos culturais ${ }^{29}$. Se na ditadura ocorreu um refluxo inicial dos movimentos negros (inclusive com o exílio de alguns de seus principais membros, como Abdias do Nascimento) e os governos militares transformaram o mito das três raças em "doutrina" do regime, com os anos, principalmente no governo Geisel, pipocaram os movimentos negros que questionaram a situação social do negro. Tais movimentos desenvolveram a noçáo de que havia a alienação do próprio negro de sua condição como negro, não apenas como pobre.

A partir daí, o mito das três raças e o ideal da democracia racial foram combatidos, vinculados à política do branqueamento que negativizava o negro e positivava o branco. O mulato e o mestiço como símbolos nacionais foram revistos como mecanismos da dominação branca. A ideia de "povo negro" se popularizou e as representações sobre a "cultura negra" também se tornariam uma questão diretamente de interesse dos movimentos negros.

Essas mudanças estavam ligadas, evidentemente, a uma nova classe média de famílias negras que ingressara nas universidades e na sociedade de consumo. O crescimento econômico motivado pelo Es-

\footnotetext{
${ }^{27}$ SILVA JR., Hélio. Estados Unidos e África. In: ALBERTI, Verena; PEREIRA, Amílcar Araújo (Org.). Histórias do movimento negro no Brasil: depoimentos ao Cpdoc. Rio de Janeiro: Pallas; Cpdoc-FGV, 2007. p. 69.

${ }^{28}$ A primeira edição nacional de Os condenados da terra é de 1968. Cf. FANON, Franzt. Os condenados da terra. Prefácio de Jean-Paul Sartre. Rio de Janeiro: Civilização Brasileira, 1968.

${ }^{29}$ Sobre isso, Carlos Alberto Medeiros recorda: "eu me lembro de como foi o impacto que essa coisa do cabelo teve sobre mim. Primeiro, porque percebi, inclusive, que passei a ser visto de outra maneira (...) Tinha a história de ser uma coisa diferente que estava rolando, e tinha o quanto de afirmação que aquilo continha. Era uma outra visão, era uma outra coisa do negro". Cf. MEDEIROS, Carlos Alberto. Estados Unidos e África. In ALBERTI, Verena; PEREIRA, Amílcar Araújo (Org.). Histórias do movimento negro no Brasil: depoimentos ao Cpdoc. Rio de Janeiro: Pallas; Cpdoc-FGV, 2007. p. 70.
} 
tado autoritário (o "milagre brasileiro") tornou acessível o emprego de negros não apenas na produção primária de bens de consumo, mas também na indústria, de maneira que "mais negros do que nunca conseguiram obter empregos formais com oportunidades de mobilidade social, numa transição gradativa que deflagrou o início de um tipo diferente de consciência social e racial"30.

Como dissemos anteriormente, apesar da repressão aos direitos políticos, o afrouxamento do regime permitiu um período de crescimento das organizaçôes negras e da cultura negra. Surgiram organizações culturais com fins políticos tendo por base comunidades negras ou negros interessados na criação de discursos identitários de caráter étnico e racial: Grupo Palmares (Porto Alegre, 1971); Centro de Cultura e Arte Negra (São Paulo, 1972); Fundação de Estudos Afro-asiáticos (Rio de Janeiro, 1973); Sociedade Cultural Bloco Afro Ilê Aiyê (Salvador, 1974); Sociedade de Estudos da Cultura Negra no Brasil (Salvador, 1974); Instituto de Pesquisas das Culturas Negras (Rio de Janeiro, 1975); Grupo de Trabalho André Rebouças (Niterói, 1973), Centro de Estudos Brasil-África (São Gonçalo, 1975); Instituto Brasileiro de Estudos Africanistas (São Paulo, 1975); Núcleo Cultural Afro-brasileiro (Salvador, 1976); Movimento Unificado contra a Discriminação Racial, depois Movimento Negro Unificado (Sáo Paulo, 1978); Bloco Afro Male Debalê (Salvador, 1979); Centro de Cultura Negra (São Luís, 1979); Bloco Afro Olodum (Salvador, 1979); Associação Cultural Zumbi (Maceió, 1979), entre tantos.

Entre os grupos mais evidentemente culturais, destacou-se o papel inspirador do Ilê Aiyê, ao propor um "retorno à África", a busca de origens na velha mãe negra. Os movimentos culturais estavam em ação na sociedade. Desde a primeira metade da década já ocorriam as festas "Black Rio", que reunia símbolos da cultura negra na capital fluminense ${ }^{31}$.

Boa parte desses movimentos esteve ligada às universidades e vinculava o caráter acadêmico a uma militância pró-identidade negra. Um desses grupos de trabalhos, sediado na Universidade Federal Fluminense (UFF), em Niterói, foi o Grupo de Trabalho André Rebouças, fundado em 1973, justamente por Beatriz Nascimento. Congregava acadêmicos(as) negros(as) e colaboraçóes de estudiosos como Eduardo Oliveira Oliveira, Juana Elbeins dos Santos, Ivonne Maggie, Décio Freitas e Carlos Hasenbalg. Afinal, podemos situar a origem daqueles discursos racialistas que surgiram contra o filme de Diegues.

Beatriz Nascimento nasceu em Sergipe em 1942 e migrou com a família ainda criança para o Rio de Janeiro, onde cursou história na Universidade Federal do Rio de Janeiro (UFRJ), entre 1968 e 1971. Estagiou como pesquisadora no Arquivo Nacional e tornou-se ativista dos movimentos culturais e políticos negros cariocas, ajudando na articulação das organizaçóes negras nos dois lados da Guanabara e mantendo contatos com movimentos negros do Brasil inteiro, inclusive com o Movimento Negro Unificado que surgiria em $1978^{32}$. Há registros de entrevistas e textos em jornais de circulação nacional tais como a Revista de Cultura Vozes, Estudos Afro-asiáticos, Opiniāo, Folha de S.Paulo etc. Nascimento passara a refletir não só sobre o lugar do negro em sociedade, mas, fundamentalmente, sobre a autoimagem negra no Brasil.

Em 1974, na revista Vozes, escrevia:

Não se pode incorrer na perpetuação de mistificaçôes, de estereótipos que remontam às origens da vida histórica de um povo que foi arrancado de seu habitat, escravizado e violentado na sua História real (...).

Quem somos nós, pretos, humanamente? Podemos aceitar que nos estudem como seres primitivos? Como

\footnotetext{
${ }^{30}$ SANSONE, Livio. Negritude sem etnicidade. Salvador: Edufba, 2006. p. 43.

${ }^{31}$ FRIAS, Lena. Black Rio - o orgulho (importado) de ser negro no Brasil. Jornal do Brasil, Rio de Janeiro, 17 jul. 1976. Caderno B, p. 1, 4-6.

${ }^{32}$ Cf. depoimentos em ALBERTI, Verena; PEREIRA, Amílcar Araújo (Org.). Histórias do movimento negro no Brasil: depoimentos ao Cpdoc. Rio de Janeiro: Pallas; Cpdoc-FGV, 2007. p. 70.
} 
IMAGEM, RAÇA E HUMILHAÇÃO NO ESPELHO NEGRO DA NAÇÃO:

CULTURA VISUAL, POLÍTICA E “PENSAMENTO NEGRO” BRASILEIRO DURANTE A DITADURA MILITAR

Francisco das Chagas Fernandes Santiago Júnior

expressóes artísticas da sociedade brasileira? Como classe social, confundida com todos os componentes da classe economicamente rebaixada, como querem muitos? Pergunto em termos de estudo. Podemos ser estudados, ser confundidos com os nordestinos pobres? Com os brancos pobres? Com os índios?

(...)

Não será possível que tenhamos características próprias, não só em termos “culturais", sociais, mas em termos humanos? Individuais? Creio que sim. Eu sou preta, penso e sinto assim [grifos nossos] ${ }^{33}$.

Anos antes da polêmica fita de Diegues, Beatriz indagava sobre o negro "real" e sobre a imposição de um conjunto de imagens culturais que o reduziam às expressóes simbólicas do Brasil, alijando-o de sua especificidade. Questionava a constituição de uma imagem da cultura negra por agentes externos a ela, evidenciava como essas imagens eram estranhas à vivência da própria população negra e como elas, de fato, mostravam apenas o mundo que a hegemonia branca queria criar:

As manifestaçóes preconceituosas são tão fortes que, por parte de nossa intelectualidade, de nossos literatos, de nossos poetas, da consciência nacional, vamos dizer, somos tratados como se vivêssemos ainda sob o escravismo. A representação que se faz de nós em literatura, por exemplo, é a de criado doméstico, ou, em relação à mulher, a da concubina do período colonial. $\mathrm{O}$ aspecto mais importante do desleixo dos estudiosos é que nunca houve tentativas sérias de nos estudar como raça [grifos nossos].

(...)

Os artistas, intelectuais e outros brancos, diante da crise do pensamento e da própria cultura do Ocidente, voltam-se para nós como se pudéssemos mais uma vez aguentar as suas frustrações históricas. É possível que agora, no terreno das ideias e das artes, continuemos a ser "os pés e as mãos" desta Sociedade Ocidental? Acham eles que por frequentarem candomblé, fazerem músicas que falam de nossa alegria, sabedoria e outros estereótipos, podem também subtrair a nossa identidade racial. Se um jovem loiro, burguês, intelectual brilhantíssimo, após alguns anos de estudo de uma de nossas manifestações chegar à conclusão que é mais preto do que eu, o que eu sou? ${ }^{34}$

O negro seria, portanto, um outro não apenas cultural ou étnico, mas racial, específico e obliterado pela visão do branco. Nascimento não reconhecia as imagens da literatura clássica como representaçóes de seu povo, de seus iguais raciais, mas táo somente semelhantes ao que os brancos eram capazes de criar para dar conforto às próprias vidas. Essa é uma das matrizes discursivas que está na base da intervenção de Nascimento quando do lançamento de Xica da Silva, dois anos depois. A mesma matriz reaparece em 1981, na cidade de Salvador, durante o Seminário Cinema e Descolonização, organizada pela Sociedade Brasileira de Estudos da Cultura Negra (Secneb), com direção de Juana Elbein dos Santos, antropóloga ativista na defesa dos direitos e visibilidades da comunidade nagô baiana. Naquele evento, Nascimento expunha:

Vejam bem que Xica da Silva surge num momento em que toda uma faixa etária de jovens negros se preocupa em protestar contra discriminação racial através do som e das danças do Black Soul nas grandes cidades do Brasil. Sua nova identidade é a dos Muhamad Ali, dos James Brown, dos Malcom X e de outros líderes que lutaram para pôr fim à crise racial americana. Vivenciamos como essa preocupação cinematográfica que surge a partir de Xica da Silva atua como um banho de água fria numa população potencialmente produtiva;

\footnotetext{
${ }^{33}$ NASCIMENTO, Beatriz. Por uma história do homem negro. In: RATTS, Alex (Org.). Eu sou Atlântica: sobre a trajetória de vida de Beatriz Nascimento. São Paulo: Imprensa Oficial do Estado de São Paulo; Instituto Kuanza, 2007. p. 93. (publicado originalmente em: Revista de Cultura Vozes, v. 68, n. 1, p. 41-45, 1974.)

${ }^{34}$ Ibidem, p. 94-96.
} 
enquanto esses jovens e não jovens buscam sua identidade racial positiva, é feita uma obra de arte que volta a figurar uma escrava que aceita a aliança com o poder colonial ${ }^{35}$.

$\mathrm{Na}$ época do seminário, porém, já havia ocorrido uma mudança fundamental, uma vez que a abertura política do regime militar permitira a organização de movimentos políticos de caráter racial, sendo o mais famoso deles o Movimento Negro Unificado, de 1978. Ainda assim a reflexão do cinema como produtor de uma imagem do negro que não o representava demonstra a constituiçáo de uma indagação da imagem do negro a partir da tentativa de correspondência entre autoimagem negra, imagem produzida pelo outro (branco) e desnivelamento entre ambos. A emergência da imagem do negro no cinema permitia a formulaçáo de questóes referentes a uma agenda política que se desenvolviam a partir de questionamentos sobre produtores (brancos), produtos (filmes) e receptores (negros) na cultura das imagens.

O seminário organizado pela Secneb em 1981 constitui uma ação nesse processo. O objetivo básico de sua organizadora, Juana Elbein, fora produzir um questionamento sobre a criação de imagens do negro e sua cultura no cinema, de maneira a criar bases para que os próprios negros se tornassem produtores de suas próprias imagens. Tratava-se de postura tática da divulgação do Secneb, que, ao revisar a tradição cinematográfica brasileira a partir da imagem do negro, aproximava as comunidades negras nagôs do arsenal de códigos culturais dos profissionais de cinema, de maneira a embasar futuras traduçôes dos sistemas culturais afro-brasileiros ${ }^{36}$.

No seminário mencionado, Muniz Sodré, cujas obras e artigos, desde os anos 1970, atacavam a maneira como o cinema brasileiro compunha uma imagem do negro, apontava

(...) determinada consciência possível do intelectual progressista que (...) não consegue ver acertadamente a posição cultural do negro (...) Eu acho que a coisa teria de ser encaminhada mais para a revisão dos padróes teóricos que informam a possibilidade de pensar que os intelectuais de esquerda transam. Um grande "grilo" seu é não poder ver o imediatamente político na cultura negra, ou nos fatos negros, ou nos fatos indígenas, ou em qualquer fato. Ele não vê o político se traduzir imediatamente a partir das possibilidades que tem de entender que é política ${ }^{37}$.

Muniz Sodré de Araújo Cabral foi outro profissional formado em meio acadêmico. Baiano de Sáo Gonçalo dos Campos, nascido em 1942, formado em direito pela Universidade Federal da Bahia (UFBA) em 1964, Sodré seguiu em mestrado na França, em sociologia da comunicação. Concluiu doutorado em letras pela UFRJ, na década de 1970, passando a publicar intensamente, inclusive sobre a questão da cultura negra. Sodré dedicou-se a uma sólida carreira acadêmica a partir dos anos 1960, e contemporâneo da expansão das comunicações de massa no Brasil, refletiu sobre aspectos de sua configuração na formação da cultura brasileira.

Nos anos 1980 publicou dois importantes livros nos quais refletia diretamente sobre o complexo simbólico da cultura negra, levantando as importantes questóes sobre a definição de um conceito de cultura própria à heterogeneidade brasileira: A verdade seduzida: por um conceito de cultura no Brasil, de 1983; e O terreiro e a cidade: a formação social negro-brasileira, de 1988.

\footnotetext{
${ }^{35}$ NASCIMENTO, Beatriz apud XAVIER, Ismail. Cinema e descolonização. Filme Cultura, ano XV, n. 40, p. 25, ago./ out. 1982.

${ }^{36}$ A propósito, Orlando Senna escreveu anos depois: "Juana promove a formação de uma equipe iniciática de cinema para a realizaçáo dos filmes produzidos pela Secneb, no intuito de reduzir os ruídos culturais na abordagem e interpretaçáo dos temas (...) chegar a um grupo de artistas e técnicos altamente familiarizados com o complexo cultural afro-brasileiro e pessoalmente integrados em seus princípios existenciais". Cf. SENNA, Orlando. Viver e morrer, o último quilombo. Filme e cultura, Rio de Janeiro, n. 41/41, p. 66, maio 1983.

${ }^{37}$ SODRÉ, Muniz apud XAVIER, Ismail. Cinema e descolonização. Filme Cultura, ano XV, n. 40, p. 25, ago./out. 1982.
} 
Em 1983, Sodré apresenta uma sólida análise da questão do "olhar branco" que idealiza a herança negra pela via da mestiçagem:

Desta maneira, Chica da Silva seria, ao mesmo tempo, um pouco de Macunaíma (Mário de Andrade), algo de João Miramar (Oswald de Andrade), muito do ideologema da negra sedutora de senzala (Gilberto Freyre), bastante dos estereótipos sensualistas da mulata (Gilberto Freyre, folcloristas, mass media), algo do discurso doutrinário da democracia racial brasileira (manuais escolares, pronunciamentos oficiais etc.), algo do ufanismo nacionalista de determinados momentos das escolas de sambas cariocas, algo do mito da esperteza do malandro. Este conjunto sincrético de discursos, apresentado pelo cinema, televisão e por ideólogos do culturalismo como um traço permanente de verdade, uma constante estrutural da sociedade brasileira ${ }^{38}$.

O autor observou como a idealização do negro é uma variante da constituição das imagens nacionais que tomam um "outro" ocidental interno ao qual deve posicionar e domar. Segue-se em $A$ verdade seduzia e, mais tarde, em $O$ terreiro e a cidade uma visão sobre as diferentes interpenetraçóes de imagens dos negros que não os representam, mas os tipificam, transformando-os em objetos segundo certo campo de referência que trabalha a integração nacional.

Esses intelectuais contaram com a ajuda de muitos pensadores, intelectuais, críticos culturais e jornalistas como Sérgio Augusto ou Carlos Hasenbalg, argentino residente no Brasil interessado nas questôes raciais brasileiras, que ajudaram na sedimentaçáo de suas reflexôes.

Grosso modo, as falas de Maria Beatriz Nascimento e Muniz Sodré permitiam a composição de identidades étnico-raciais, as quais competiam com as propostas mestiças que seguiam o ideário modernista em finais dos anos 1970. A questão que gostaria de ressaltar aqui é que a racialidade e a etnicidade construídas naquele contexto, ou seja, a ideia de uma cultura negra e afro-brasileira foi instrumentalizada, também, para compor uma noção positivada de raça no Brasil ${ }^{39}$.

Uma nova geração de intelectuais (antropólogos, sociólogos, historiadores etc., nem todos negros, há que se frisar) produziu inflexão na forma como a imagem negra era debatida. O traço mais significativo desses discursos foi o reconhecimento da raça como categoria importante da sociedade brasileira, e usá-la como instrumento pelo qual se pode reivindicar novas imagens e novas formas de participação na sociedade, inclusive desarticulando velhas ideologias da identidade nacional.

\section{Retórica da imagem como retórica da humilhação}

Apontar a ação de intelectuais como Beatriz Nascimento ou Muniz Sodré permite constatar os anos 1970 como período de emergência de concepçóes alternativas, no caso específico da reformulaçáo dos parâmetros raciais no Brasil.

A afirmação do discurso étnico-racial nos anos 1970 articulou novidades no contexto histórico, a qual pode ser acompanhada nas polêmicas do campo cinematográfico brasileiro e rastreada para além dele. A racialização emergiu de forma explícita nas reaçóes às produçóes e discussóes sobre o negro do campo cinematográfico, alimentando o crescimento de um sentimento de pertença entre diversos indivíduos que acreditavam partilhar experiências de humilhação.

\footnotetext{
${ }^{38}$ SODRÉ, Muniz. A verdade seduzida: por um conceito de cultura no Brasil. Rio de Janeiro: Codecri, 1983. p. 173.

39 Importante frisar que estamos falando de um processo de racialização que se inicia nos debates mais amplos sobre a cultura e a identidade negra, mas que não se propôs, na época, como uma posição hegemônica nas discussóes do "pensamento negro", mas como um discurso em emergência. A racialização desenvolvia-se junto à etnicização do negro, sem que, contudo, esses dois processos sociais estivessem submetidos um ao outro. Infelizmente, neste artigo não é possível observar as múltiplas ramificações históricas e teóricas dessa questão.
} 
Os discursos trabalhados neste texto apresentam experiências de humilhação articuladas nas imagens cinematográficas. $\mathrm{O}$ pensamento negro articulou conceitos que sistematizaram a imagem dos negros em filmes como Xica da Silva ou Tenda dos Milagres, mostrando como eles diminuem o "negro" apresentado. $\mathrm{O}$ ponto de vista do artista e intelectual branco que elabora a imagem do negro e nada mais faz do que atualizar os estereótipos sobre este, na perspectiva do "outro-negro", permitiu a Nascimento e Sodré destacar o tipo de ação humilhante que o branco realiza.

O ponto de encontro entre os discursos é que os intelectuais negros se reconhecem nas imagens dos filmes como o "outro" humilhado. Podemos detectar esse ponto pelo fato de que os discursos de Beatriz Nascimento, entre tantos, tornam-se discursos racialistas ao se fazerem discursos do humilhado que decide denunciar o próprio rebaixamento.

As películas de Carlos Diegues e de Nelson Pereira dos Santos, bem como os próprios cineastas, foram apontados como sintomáticos de uma prática cultural do rebaixamento. As imagens dos filmes, produzidas por brancos, na concepção dos pensadores negros, negavam o negro brasileiro. Mesmo ao atribuir-lhes visibilidade, o faziam de forma desigual, estereotipada e falsa.

Ora, a racionalidade do ato de humilhação consiste em incutir um tipo específico de sofrimento ao se realizar como ataque à interioridade dos negros, que, atingidos individual e coletivamente, são desvalorizados e inferiorizados em suas posiçôes ${ }^{40}$. Como chama atenção Pierre Ansart, a humilhação é uma poderosa arma de repressão, ou pode ser usada como instrumento para ativar a liberaçáo. Contra a retórica humilhante que estaria contida nos filmes de Diegues e de Santos, os escritos de Frederico, Hasenbalg, Nascimento e Sodré criaram contraimagens que rejeitavam as concepçóes de relaçôes étnico-raciais atenuadas no Brasil e do hábito de culturalizar o negro, reduzindo-o à sua "cultura", o que era compreendido por intelectuais como um traço de despolitização do negro.

A retórica da (anti) humilhação era uma forma de repolitizar o negro. A denúncia virulenta da qualidade da imagem de cinema "branca", de seu olhar idealizador do negro como história, cultura e diversão, foi redefinida em contraposição à experiência negra que as fitas não apresentavam. Tomando como referência o olhar branco sobre o passado nacional e a mulher negra em Xica da Silva, por exemplo, a fita de Diegues fora ressignificada como um desrespeito à memória negra e à verdadeira escravidão histórica.

A humilhação era tomada como maior conforme se percebia que a intelectualidade "branca" não compreendia a vileza do papel que estava cumprindo. Xica da Silva e Tenda dos Milagres investiam em imagens do negro supersexualizado, da permissividade e do carnavalesco, e isso foi identificado como um processo de humilhação.

Aquilo que para uns era um retrato da brasilidade, no recorte racial montado nos anos 1970, tornou-se um retrato humilhante de "outro povo" — o negro — dentro da nação. Parte da audiência não se reconheceu nas imagens, considerou-as alheias, viu-se retratada como objeto. As críticas a Xica da Silva e Tenda dos Milagres são um sinal do deslocamento histórico no debate político. Ao entrar na defensiva demonstrando sua revolta, e colocando-se como porta voz de uma rejeição coletiva, Beatriz Nascimento e Muniz Sodré procuraram articular transformações, numa reversão que colocara o branco sobre mira ao mostrar as implicaçóes da produção de suas imagens. Ao mostrar o branco como agente do sofrimento, contestava-se a ordem social de uma perspectiva racializada.

\footnotetext{
40 Sobre a ideia de humilhação como um processo historicamente identificável cf. ANSART, Pierre. As humilhações políticas. In: MARSON, Izabel; NAXARA, Márcia (Org.). Sobre a humilhação: sentimentos, gestos, palavras. Uberlândia: Edufu, 2005. p. 15-30.
} 
IMAGEM, RAÇA E HUMILHAÇÃO NO ESPELHO NEGRO DA NAÇÃO:

CULTURA VISUAL, POLÍTICA E “PENSAMENTO NEGRO” BRASILEIRO DURANTE A DITADURA MILITAR

Francisco das Chagas Fernandes Santiago Júnior

Em 1974, Beatriz Nascimento, vale lembrar, antes de Xica da Silva, já refletia:

A todo momento o preconceito racial é demonstrado diante de nós, é sentido. Porém como se reveste de uma certa tolerância, nem sempre é possível percebermos até onde a intenção de nos humilhar existiu. De certa forma, algumas destas manifestaçôes já foram inclusive incorporadas como parte nossa. Quando, entretanto, a agressão aflora, manifesta-se uma violência incontida por parte do branco, e mesmo, nestas ocasióes (...). Temos, vamos dizer, uma atitude de amor e ódio por nós mesmos; a presença, o confronto com o outro nos incomoda também [grifos nossos] $]^{41}$.

Aqui, o encerramento de Beatriz Nascimento no Opiniāo é emblemático: "o sr. Diegues cai no oposto, esquecendo que criação requer crítica, crítica sua sr. Diegues. O senhor me faz pensar que sua classe de acordo com a sua tradição está dentro da Casa Grande jogando pratos de comida na Senzala. Foi o que seus antepassados fizeram conosco" ${ }^{\text {"42 }}$. Nascimento, literalmente, transforma o cinema no "outro" do povo negro.

\section{Considerações finais}

Inicialmente, ao acompanhar as reaçóes às imagens de alguns filmes dos anos 1970, observamos a sistematização inicial de uma nova classificação racial no Brasil, a qual se realiza na positivação do polo negro do espectro racial e na transformação da raça em vetor político. Isso implicou, e aqui está o interesse por essa pesquisa, contrapor às imagens do cinema discursos que as interpretavam a contrapelo.

O campo cinematográfico, ao contrário do que advogaram os intelectuais negros contemporâneos, não estava interessado em reproduzir a mesmidade racista. $\mathrm{O}$ objetivo de Diegues e Santos fora fazer da imagem do negro e sua cultura formas políticas capazes de apontar novos rumos para a nação. Infelizmente, não há espaço neste texto para mostrar como o ideal de mestiçagem que informava os filmes combatidos pelo pensamento negro deu visibilidade e politizou o negro ${ }^{43}$. Náo apenas a concepçáo de raça mudara entre intelectuais negros, mas também a de mestiçagem. Tratamos, portanto, de alguns aspectos dos conflitos de interpretação que deram densidade às imagens do cinema.

O movimento de racialização explícita de Nascimento e outros politizou as imagens do cinema pelo negativo: os produtores e produtos do cinema foram transformados em alienadores quando questionados por um prisma racial. Criando um novo padrão identitário, a raça polar surgia quando o pensamento negro identificava o olhar branco humilhador na imagem humilhante do cinema. Com a imagem branca humilhante, surgiu o negro humilhado, mas agora se esforçando para contra-atacar a fonte de seu rebaixamento.

Contudo, em vez de regularidades discursivas ou brigas entre cineastas, filmes e autores em jornais, o que se observa nesse contexto foram mudanças nas afetividades políticas brasileiras, na medida em que se deslocou a maneira de lidar com o problema do negro pela aceitaçáo da existência da humilhação contida nas imagens do "negro" produzidas pelos "brancos". Os discursos veiculados na imprensa

\footnotetext{
${ }^{41}$ NASCIMENTO, Beatriz. Por uma história do homem negro. In: RATTS, Alex (Org.). Eu sou Atlântica: sobre a trajetória de vida de Beatriz Nascimento. São Paulo: Imprensa Oficial do Estado de Sáo Paulo; Instituto Kuanza, 2007. p. 94. (publicado originalmente em: Revista de Cultura Vozes, v. 68, n. 1, p. 41-45, 1974.)

${ }^{42}$ Ibidem.

${ }^{43}$ BRUGGER, Silvia. Clara Nunes: o canto como missão. RECIIS, Rio de Janeiro, v. 4, n. 3, p. 103-117, set. 2010; SANTIAGO JR., Francisco das C. F. Imagens do candomblé e da umbanda: religiosidade e etnicidade no cinema brasileiro (1974-1984). Tese (Doutorado em História). Programa de Pós-Graduação em História, Universidade Federal Fluminense, Rio de Janeiro, 2009.
} 
foram uma forma social da rejeição dessa humilhação. Isso demonstra, como coloca Pierre Ansart, que os agentes humilhados (Nascimento e Sodré) e seus aliados (tais como Hasenbalg) são produtores e produtos do processo de afirmação da dignidade, rejeitando a "temporalidade tal como construída pelo poder" (ou pelo que identificam como poder) e criando possibilidades de futuro e transformação da realidade social à qual póem em nova perspectiva ${ }^{44}$.

Compreende-se assim que a cultura política é repleta de um conjunto de atitudes e sistemas de classificação e hierarquização atuantes e modificados na cultura visual. Num dado contexto, os sujeitos atualizam, reproduzem e modificam sua relação com o campo político. Como os padróes e afetividades políticos são mutantes e sofrem influências de inúmeros campos sociais, o cinema criou imagens sobre o negro que suscitaram disputas, as quais permitiram a emergência de novas categorias políticas e raciais. Essas formas estão relacionadas a uma nova noção de raça pensada e imaginada a partir de uma sensibilidade política de rejeição vigorosa do que se considerara a fonte do sofrimento: a imposição da imagem falsa do negro no cinema. Na imprensa criou-se um meio social de reversão da reificação do negro ${ }^{45}$.

A nova semântica da raça é tanto sinal de mudança quanto é ela própria "a” mudança, uma alteração na sensibilidade social que aponta para uma nova sensibilidade política, um traço das culturas políticas brasileiras que começaram a se formar no regime militar. A racialização que apontamos nesse texto tornou-se um recurso possível do campo político nacional.

Chamamos atenção para o fato de que a racialização ocorre também na cultura visual, sinalizando para novas pesquisas ${ }^{46}$. Neste artigo, aparece o que podemos chamar de escritura de imagens raciais, textos que discutem imagens do negro e apontam uma dicotomia entre imagem e representação do negro. Isso significa que a elaboraçáo da identidade negra no Brasil atingiu níveis de complexidade que integraram campos sociais diversos na visualidade. A cultura visual não é constituída unicamente pelas imagens visuais propriamente ditas, mas também pelo conjunto de discursos que são mobilizados para reagir, enquadrar, transformar e atualizar imagens diversas.

As polêmicas aqui mostradas foram um traço de um movimento de redefinição da identidade do negro brasileiro a partir da imagem racializada. A presença de metáforas visuais nos discursos, expressões como "espelho", "visão de mundo", "posição", "introjeção" etc., apontam para uma maneira de construir uma retórica racial.

Tal como chama atenção Paul Gilroy, o estudo das formas visuais em seus diversos circuitos sociais de integração (da crítica de cinema às matérias de jornais e obras acadêmicas) demonstra a constituição histórica das hierarquias raciais na formação do horizonte político de nossa época. A história da recente racialização brasileira precisa ser escrita, apontando suas disputas internas, relaçôes com a diáspora negra e manifestaçóes variadas na sociedade. A relação texto-imagem do negro é uma proposta de trabalho.

\footnotetext{
${ }^{44}$ ANSART, Pierre. As humilhações políticas. In: MARSON, Izabel; NAXARA, Márcia (Org.). Sobre a humilhação: sentimentos, gestos, palavras. Uberlândia: Edufu, 2005. p. 20.

${ }^{45} \mathrm{O}$ rebaixamento do sujeito a um nível de objeto que desencadeia uma dimensão de perda está na base do processo humilhante. Cf. AZEVEDO, Ana Vicentini. Da humilhação à sublimação: a vida da fantasia na psicanálise e na literatura. In: MARSON, Izabel; NAXARA, Márcia (Org.). Sobre a humilhação: sentimentos, gestos, palavras. Uberlândia: Edufu, 2005. p. 49-84.

${ }^{46}$ Pretendemos, no futuro, desenvolver uma pesquisa acurada sobre a questão da imagem do negro nos escritos de inúmeros intelectuais negros desde o jornal O Quilombo até os anos 1970. Essa investigação será fundamental para verificação das interpretaçóes expostas neste artigo.
} 